\title{
Marketing Politik Pemenang Anggota Legislatif Dapil 3 Partai Gerindra Kota Padang
}

Yudiana Nofriani, Susi Fitria Dewi

Program Studi Pendidikan Pancasila dan Kewarganegaraan

Universitas Negeri Padang

E-mail: yudiana144@gmail.com

\section{ABSTRAK}

Penelitian ini dilatarbelakangi dengan menangnya Partai Gerindra Kota Padang selama 2 periode dan meningkatnya keterwakilan kursi di parlemen. Tujuan penelitian ini adalah untuk menganalisis strategi Partai Gerindra Kota Padang dalam memenangkan pemilu 2019 di Kota Padang. Jenis penelitian ini adalah kualitatif dengan menggunakan metode deskriptif. Pemilihan informan dilakukan dengan teknis purposive sampling dengan informan penelitian Ketua DPC Partai Gerindra Kota Padang, wakil ketua, caleg dari dapil 3, dan masyarakat. Hasil penelitian ini menujukkan bahwa Partai Gerindra Kota Padang memiliki strategi dalam memenangkan pemilu 2019 di Kota Padang dilihat dari marketing politik 4 P yaitu product (produk), place (penempatan), price (harga), dan promotion (promosi). Sosok Prabowo Subianto yang telah melekat di hati masyarakat juga menjadi pendongkrak agar Partai Gerindra menang dalam pemilihan umum.

Kata Kunci: marketing politik, Partai Gerindra, pemilu legislatif

\section{ABSTRACT}

This research is motivated by the victory of the Gerindra Party with 2 periods and the increasing number of seats in parliament in Padang. The purpose of this study is to analyze the strategy of Gerindra in winning the 2019 election in Padang City. This type of research is qualitative using descriptive methods. The selection of informants was carried out using a purposive sampling technique with research informants as Chairperson of Gerindra Party district Padang, deputy chairman, candidates from electoral district 3, and the community. The results of this study indicate that the Gerindra has a strategy in winning the 2019 elections in the city of Padang in terms of $4 P$ political marketing, namely product, place, price, promotion. The figure of Prabowo Subianto, who has been embedded in the hearts of the people also a booster so that the Gerindra Party wins the general election.

Keywords : political marketing, Gerindra Parties, legislative elections

(c) (†) (?) $\begin{aligned} & \text { This work is licensed under the Creative Commons Attribution-ShareAlike 4.0 International License. (22019 } \\ & \text { by author. }\end{aligned}$ 


\section{PENDAHULUAN}

Mengkaji

mengenai

kemenangan Partai Gerindra dapat membawa dampak positif bagi masyarakat yaitu dengan mencerdaskan masyarakat secara politik. Masyarakat mengetahui dan mendapatkan ilmu mengenai strategi yang dilakukan oleh Partai Gerindra dalam memenangkan pemilu. Dampak positif bagi partai lain yaitu bisa belajar kepada partai-partai yang berhasil memenangkan pemilu. Kemudian dapat mengadopsi strategi partai tersebut dan mempraktekkan ke dalam partainya sendiri. Artikel ini ingin mengungkapkan strategi apa yang di lakukan Partai Gerindra untuk memenangkan pemilu 2019 di Kota Padang.

Pembahasan mengenai strategi kemenangan partai politik sebelumnya sudah diteliti oleh Rosyid dengan judul Strategi Pemenangan Caleg Partai Gerindra pada Pemilihan Umum Legislatif 2014 (Studi Tentang Marketing Politik Caleg DPRD Provinsi Jawa Timur). Hasil dalam penelitian ini mengungkap bahwa strategi caleg menggunakan marketing politic dengan metode $4 \mathrm{P}$, yaitu positioning, policy, party, dan presentation. Kemudian penelitian oleh Ridduwan Syah tahun 2019 dengan Judul Strategi Politik Partai Gerindra dalam Perolehan Kursi Anggota Legislatif Kota Banda Aceh pada Pemilu Tahun 2014. Hasil penelitian ini adalah Peningkatan perolehan kursi Anggota Legislatif Partai Gerindra Provinsi Aceh pada pemilu 2014 adalah adanya asfiliasi dengan partai lokal yang berkuasa di Aceh yaitu partai Aceh.

Sedangkan penelitian oleh Darmansyah yang berjudul Strategi
Pemenangan Partai Demokrasi Indonesia Perjuangan (PDI-P) di Kabupaten Bener Meriah (Studi Pada Pemilu Legislatif Tahun 2014). Hasil penelitian menunjukan bahwa ada lima strategi rekrutmen Caleg dari tokoh masyarakat yakni memahami kondisi daerah pemilihan, perluasan basis partai, menjalin komunikasi langsung, sosialisasi program kerja partai dan money politics. Ada juga yang meneliti partai lain oleh Andriyanto dengan judul Strategi Dewan Pimpinan Daerah II Partai Golongan Karya Pada Pemilihan Umum Legislatif di Kabupaten Siak Tahun 2014. Hasil penelitian menunjukkan bahwa terdapat beberapa strategi yang dilakukan merekrut calon anggota legislatif yang berpotensi memenangkan pemilihan umum, membentuk Jaringan Tim Sukses pada setiap kecamatan, menampilkan isu yang tepat sesuai dengan ke inginan masyarakat yakni isu pertanian, isu pendidikan, isu insfrastruktur dan isu ketenagakerjaan.

Penelitian oleh Nurdiansyah menunjukkan bahwa Partai Gerindra membidik segmen masyarakat kelas bawah dan segmen pemuda, petani, nelayan, buruh, guru, dan pedagang kecil. Kedua, Partai Gerindra masih mengandalkan sosok Prabowo Subianto sebagai sosok yang menjadi pendongkrak utama perolehan suara partai. Penelitian ini memiliki perbedaan dengan penelitian sebelumnya yang mengkaji mengenai strategi partai Gerindra di Jawa Timur dan Banda Aceh, Partai Demokrasi Indonesia Perjuangan (PDI-P) di Kabupaten Bener Meriah, dan Partai golkar di Kabupaten Siak. Sedangkan penelitian ini meneliti mengenai 
streategi Partai Gerindra dalam memenangkan pemilu pada tahun 2019 di Kota Padang.

Dalam Pemilu 2019 KPU telah menetapkan 16 partai politik peserta yang ikut dalam pemilu. Di antaranya Partai Nasional Demokrat (Nasdem), Partai Kebangkitan Bangsa (PKB), Partai Keadilan Sejahtera (PKS), Partai Demokrasi Indonesia Perjuangan (PDIP), Partai Golongan Karya (Golkar), Partai Gerakan Indonesia Raya (Gerindra), Partai Demokrat, Partai Amanat Nasional (PAN), Partai Persatuan Pembangunan (PPP), Partai Hati Nurani Rakya (Hanura), Partai Bulan Bintang (PBB), Partai Keadilan dan Persatuan Indonesia (PKPI), dan Partai pemula yaitu: Partai Perstuan Indonesia (Perindo), Partai Berkarya, Partai Gerakan Perubahan Indonesia (Garuda), dan Partai Solidaritas Indonesia (PSI). (KPU Kota Padang).

Gerindra memenangkan pemilu dua kali periode berturut-turut. Periode pertama pada tahun 2014-2019 dan 2019-2024, pada pemilu 2014 mendapatkan perolehan suara 13,33\% dan tahun 2019 mendapatkan perolehan suara $21,66 \%$. Ini tentu merupakan peningkatan yang sangat pesat bagi Partai Gerindra dalam pemilihan umum di Kota Padang. Pada tahun 2014 Partai Gerindra Kota Padang mendapatkan 6 kursi anggota legislatif yang duduk di parlemen.

Sedangkan pada tahun 2019

Partai Gerindra Kota Padang mendapatkan peningkatan kursi anggota legislatif menjadi 11 kursi yang duduk di parlemen. Peningkatan ini merupakan peningkatan yang sangat signifikan bagi partai Gerindra merupakan prestasi besar dengan bisa memenangkan pemilu dengan dua kali periode. Partai Gerindra juga mendapatkan 15 caleg perempuan dari 45 caleg. Sehingga mendapatkan kuota $33 \%$ melebihi dari syarat kuota perempuan yang harus ada di partai politik.

\section{METODE PENELITIAN}

Jenis penelitian yang digunakan adalah kualitatif dengan metode deskriptif. Sebab peneliti berusaha membuat deskripsi, gambaran tentang suatu peristiwa sebagaimana yang terjadi. Lokasi penelitian yaitu di Kantor DPC Partai Gerindra Kota Padang. Penulis menggunakan teknik purposive sampling karena dianggap bahwa informan kunci yang benar dalam memahami persoalan yang terjadi. Informan penelitian ini adalah ketua, wakil ketua, bendahara, anggota yang duduk dari dapil 3 dan masyarakat. Sumber data dalam penelitian ini menggunakan data primer dimana data diperoleh dari hasil observasi dan wawancara di lapangan. Selanjutnya data sekunder dapat diperoleh dari hasil studi dokumentasi di lokasi penelitian. Teknik pengumpulan data dilakukan melalui observasi, wawancara dan studi dokumentasi. Dalam menguji keabsahan data penelitian, penulis menggunakan teknik triangulasi sumber. Selanjutnya data yang diperoleh akan dianalisis melalui tahap reduksi data, penyajian data dan penarikan kesimpulan.

\section{HASIL DAN PEMBAHASAN}

Dalam marketing politik Pemenang Anggota Legislatif Dapil 3 Partai Gerindra Kota Padang terdapat empat elemen, yaitu:

\section{a. Product (produk)}

Merupakan suatu yang kompleks, dimana pemilih akan menikmati setelah suatu partai atau 
seorang kandidat terpilih. Produk politik menurut Niffeneger (Firmanzah: 2008) dalam (Damsar: 2010) terdiri dari party platfrom (platfrom partai), past record (rekaman lampau), dan personal characteristic (karakteristik individual). Platform partai yang terdiri dari visi, ideologi, misi, tujuan, dan program partai merupakan salah satu produk yang dijual kepada pemilih, terutama pemilih rasional. Rekaman masa lampau tentang apa yang telah dilakukan sebelumnya bagi kepentingan publik ialah suatu produk yang layak dan pantas dijual kepada pemilih. Karakteristik individual berupa keteladanan dan ketokohan seseorang dalam masyarakat dapat dilihat sebagai suatu produk yang bisa dijual pada masyarakat.

Partai Gerindra menjelaskan terlebih dahulu visi, misi dan tujuan dalam kampanye kepada masyarakat dan menjelaskan program- program yang akan di kerjakan untuk lima tahun kedepan. Kemudian menjelaskan kepada masyarakat bahwasanya Partai Gerindra memiliki calon- calon legislatif yang memiliki layak jual atau bisa dikatakan berkualitas. Dimata masyarakat Partai Gerindra tidak memiliki kesalahan dari dulu sampai sekarang melainkan sangat di terima terutama masyarakat Kota Padang. Figur Prabowo Subianto sebagai Ketua Umum yang dikenal ketegasannya.

\section{b. Place (penempatan),}

Berkaitan erat dengan cara hadir atau distribusi sebuah partai dan kemampuannya dalam berkomunikasi dengan para pemilih. Ini berarti sebuah partai harus dapat memetakan struktur serta karakteristik masyarakat baik itu geografis maupun demografis. Berdasarkan hasil wawancara penentuan daerah pemilihan boleh disarankan oleh caleg-caleg yang akan mencalonkan diri. Kemudian setelah itu Partai Gerindra akan mengadakan rapat dengan pengurus dan anggota kemudian memutuskan derah pemilihan caleg-caleg tersebut sesuai dengan hasil rapat dan jumlah penduduk di daerah tersebut.

$$
\text { c. Price (harga) }
$$

Merupakan harga ekonomi dan harga psikologis. Harga ekonomi merupakan kalkulusi segala biaya yang bisa dihitung nominalnya seperti biaya iklan, publikasi, pengerahan massa, administrasi pengorganisasian. Sedangkan harga psikologi merujuk pada harga persepsi psikologis dari kandidat anggota legislatif atau top eksekutif yang ditawarkan kepada pemilihnya. Misalnya, apakah latar belakang (suku, agama, pendidikan, daerah asal, dll). Nilai ekonomi Partai Gerindra terhadap para Caleg dalam pemilihan umum dipertimbangkan atas dasar keyakinan dan juga persiapan yang matang. Setiap caleg harus yakin dan juga memiliki kesiapan baik itu dari segi biaya ataupun kesiapan mental dan harus optimis.

Dalam hal pembiayaan, berasal dari biaya pribadi caleg dan juga dana gotong royong. Dana tersebut digunakan untuk keperluan persiapan, kampanye ataupun evaluasi dan juga kepentingan lainnya seperti atribut dan lain-lain. Dana kampanye partai Gerindra Sumbar yang berasal dari dana gotong royong atau sumbangan para calon legislatif, serta dana partai politik tersebut dikumpulkan dalam suatu rekening partai dengan 
transparansi yang jelas bagi internal partai. Setiap bulan selama persiapan ataupun setelah Pemilu dilakukan, laporan keuangan dana kampanye tersebut terus dijalankan sesuai dengan keterangan. Baik itu berupa sumber dana atau bahkan aliran dana tersebut. Dalam laporan dana kampanye tersebut, terdapat sumber dana dari 45 (empat puluh lima) calon legislatif dari partai Gerindra Kota Padang dari lima wilayah pembagian di Kota Padang. Sedangkan harga psikologis pada dasarnya mengacu pada harga persepsi psikologis kandidat, seperti adanya ketertarikan terhadap kandidat, pemilih merasa nyaman dengan latar belakang etnis, agama, pendidikan, suku dan lain-lain.

\section{d. Promotion (promosi)}

Merupakan suatu usaha dalam memikat pembeli melalui teknik komunikasi dengan berbagai media seperti cetak, elektronik, maupun interpersonal. Suatu produk tertentu yang terletak pada tempat, harga harus dipromosikan dengan cara tertentu. (Damsar: 2010). DPC Partai Gerindra Kota Padang melakukan promosi melalui media cetak seperti koran, baliho dan spanduk. Pada media elektronik handphone, komputer dengan media sosial seperti whatsapp, facebook, instagram agar mereka bisa dikenal oleh masyarakat walaupun tidak bertatap muka. Mereka juga melakukan promosi interpersonal yaitu bertatap muka langsung oleh masyarakat dengan mendatangi kelompok- kelompok yang ada di masyarakat dan menjadwalkan sosialisasi kepada masyarakat.

\section{KESIMPULAN}

$\begin{array}{ccr}\text { Marketing Politik } & \begin{array}{r}\text { yang } \\ \text { anggota }\end{array}\end{array}$

legislatif dapil 3 Partai Gerindra Kota Padang adalah pertama, product yang dilakukan Partai Gerindra adalah dengan menjelaskan visi, misi, tujuan dan program kerja partai Gerindra kepada masyarakat. Kedu, place Partai Gerindra menentukan daerah pemilihan tergantung kepada saran calon legislatif dan kesepakatan bersama. Ketiga, price harga ekonomi yaitu dana yang diperoleh Partai Gerindra Kota Padang dari sumbangan 45 caleg-caleg yang akan mencalonkan diri, yang disebut sebgai dana gotong royong oleh partai. Sedangkan harga psikologi Partai Gerindra menjelaskan kepada masyarakat melalui latar belakangnya seperti suku, asal, tempat tinggal dan pendidikan agar masyarakat bisa menentukan pilihannya secara rasional. Keempat, promotion, yang dilakukan partai Gerindra melaui media cetak yaitu koran, baliho, kelender dan media elektronik handphone dan komputer dengan media sosial yaitu whatsApp, Facebook, Instagram. Faktor pendukung lainnya adalah dengan kehadiran sosok Prabowo Subianto sebagai ketua umum Partai Gerindra dikenal sangat tegas yang berada di hati masyarakat Kota Padang sehingga dapat meningkatkan suara Partai Gerindra Kota Padang yang sangat pesat.

\section{DAFTAR PUSTAKA}

Damsar. 2010. Pengantar Sosiologi Politik. Jakarta: Kencana.

Andriyanto, Eko. "Strategi Dewan Pimpinan Daerah Ii Partai Golongan Karya Pada Pemilihan Umum Legislatif di Kabupaten Siak Tahun 2014." Jom FISIP Volume 2 No. 1Februari 2015. 
Nurdiansyah, Fahmi. "Marketing Politik DPP Partai Gerindra Pada Pemilu Legislatif 2014."Jurnal Ilmu Politik, Vol 9 No 1, April 2018.

Rosyid, Halimur. 2019. "Strategi Pemenangan Caleg Partai Gerindra pada Pemilihan Umum Legislatif 2014 (Studi Tentang Marketing Politik Caleg DPRD Provinsi Jawa Timur)." Jurnal Politik dan Sosial Kemasyarakatan Vol 11 No 1 (2019).

Raudhi, Radhi Darmansyah. 2017. "Strategi Pemenangan Partai Demokrasi Indonesia Perjuangan (PDI-P) di Kabupaten Bener. "Jurnal Ilmiah Mahasiswa FISIP Unsyiah Volume 2, Nomor 3: 120 Agustus 2017.

Syah, TM Ridduwan. “Strategi Politik Partai Gerindra dalam Perolehan Kursi Anggota Legislatif Kota Banda Aceh Pada Pemilu Tahun 2014." Jurnal Ilmiah Mahasiswa FISIP Unsyiah Volume -, Nomor-: 114Mei 2019. 